\title{
Rule of Law or Law Overruled? Why the Rule of Law Should Be on the Public Administration Research Agenda
}

Stavros Zouridis

\begin{abstract}
There appears to be a remarkable contradiction between what is happening in public-administration science and in public-administration practice. In the former, legal approaches have been displaced by managerial and political approaches. This shift sharply contrasts with the continuous legalization and juridification of publicadministration practice. Public-administration practice has gradually converged with the law. Lawyers and legal scholars applaud the convergence of the law and public administration as the ultimate realization of the ideal of the Rechtsstaat. A public-administration perspective should take a more critical stance. From a publicadministration perspective, the Rechtsstaat produces both functional and dysfunctional effects. Assessing these effects requires comparative and multi-disciplinary research. Comparative research will reveal different legal and administrative traditions both within Europe and between Europe and other parts of the world. The Rechtsstaat should therefore return onto the public-administration research agenda.
\end{abstract}

\section{Introduction: From legal myopia to the law as a blind spot}

In recent decades, public-administration science has drifted away from the law. The legal approach to public administration has gradually been displaced by managerial and political approaches. Legal explanations of public administration's practices have been replaced by managerial, political, economic, psychological and narrative explanations. According to Lynn, this anti-legal temper already emerged in the 1920s in American public administration (Lynn 2009). Publicadministration scholars have had good reasons to abandon the legal perspective. Whereas the legal approach embodies the normative dimension of the state and its institutions, public-administration science aims at an empirical understanding 
of public administration's real design and behavior. Over and over, research has shown huge gaps between the actual behavior of public officials and the law on the books (e.g. Kagan 1978, Hawkins 2002, Bakker and Van Waarden 1999, Wilson 1991). Sticking to legal myopia would therefore distort an empirical understanding of public administration.

However, public-administration science has drifted too far away from the law. The behavior and design of public administration, public managers, governments and public professionals cannot be understood without taking the law into account (e.g. Cooper 2007). Tasks and responsibilities in public administration are more and more legally distributed, limited and regulated. If political and administrative decisions do not meet legal requirements, courts increasingly annul them. Public-management approaches may define a permit or a benefit as a product or as administrative performance, but these decisions are primarily legal acts. The law's impact on public administration nowadays touches the very core of every public organization.

Should we then restore the old public-administration science with its emphasis on the formal and legal sides of public administration? That would probably not be very fruitful. We would then run the risk of emphasizing a normative reality that does not exist in real-life public-administration practice. The old-style European emphasis on doctrine, legal and political theory and "raison détat" should at least be complemented by empirical theories that focus on the role of the law in public administration and the way it affects standard operating procedures and routines, decisions and policies. It will be argued in this article that at least three lines of thought have to be connected which have been separated for too long. The empirical perspective of public-administration science has to be connected with the law and legal thinking. Taken together, these empirical approaches to the law and public administration build on American research on the law in action. Merely connecting the law with public-administration practices does not suffice. We also need to connect an empirical approach on the law in action with European doctrines and theories on the Rechtsstaat.

Even though it is a Herculean task to connect these lines of thought, it is both necessary and fruitful. As argued in this article, the Rechtsstaat will reach a deadlock without public-administration research. This essayistic article can only modestly contribute to such an agenda by proposing some foundations and research directions. The main hypothesis put forward in section two is proposed as a foundation. The hypothesis claims that the law and public administration have converged. In general, public administration's actual behavior and design increasingly mirror the law. The law has become the prime instrument of government. In a way, the hypothesis in section two claims that the ideal of the Rechtsstaat is realized ever more in public-administration practice. In section three, the consequences, functions and dysfunctions of this convergence process will be assessed from a public-adminis- 
tration perspective. The concluding section contains some research directions for public administration.

\section{The convergence of the law and public administration From the rule of law to the role of law}

Any attempt to connect public administration and the law requires a clarification of these concepts. For the purposes of this article, the concept of public administration refers to the organizations of the state. These include the legislative, executive and judiciary functions of the state on all levels (from local to international) as well as the organizations surrounding these functions (e.g. advisory councils). Publicadministration science aims to explain the behavior and the design of these organizations and their management, working processes, cultures, interrelationships and so on. For a long time, the analysis of public administration started with a rough sketch of its institutional skeleton as laid down in constitutional or administrative law. In the course of the twentieth century, this way of analyzing public administration has gradually been pushed into the background of public-administration science. It appeared that organization theories, political theories, economic and psychological theories on decision-making and network governance theories better explain the actual behavior and design of public administration. Analyzing the legal institutional framework is increasingly regarded as old-fashioned and outdated because it does not reflect the empirical realities of public administration.

However, the law should not be ruled out as an explanatory variable even though its impact is conceptually difficult to grasp. The law's impact is conceptually difficult to understand because the law simultaneously affects the design and behavior of public administration and it results from the design and behavior of public administration. The organizations of the state create the law, and they are simultaneously obliged to adhere to it. Analyzing and isolating the role of the law therefore requires a clear definition of the concept of the law. Many ages of scholarly debate still have not led to a consensus on a single definition of the law or on any approach to the law (e.g. Freeman 2001). The law appears to be a multifaceted phenomenon. First, the law refers to legal forms like legislation and precedent. Second, the law can also refer to legal values and legal principles, such as legal equality and legal certainty. Third, the concept of the law has been used to refer to rights as entitlements. Finally, according to some scholars, the law refers to legal institutions (e.g. courts) or the actions of those institutions. 
Used in the context of public administration, the law primarily refers to the normative notion of the Rechtsstaat or the rule of law. ${ }^{1}$ The concept of Rechtsstaat does not solve the problem of defining the law. It only replaces it by another problem. Just as many ages of scholarly debate on the law have not led to consensus on the law, many ages of scholarly debate on the Rechtsstaat have not led to consensus on the Rechtsstaat either. Fundamentally different theories on the Rechtsstaat still compete, sometimes starting from rivaling positions. The debate usually revolves around two competing conceptions. A positivist conception of the Rechtsstaat implies that a Rechtsstaat refers to a state that conforms to its laws. Legality is the key principle of a Rechtsstaat. Many legal scholars have advocated the positivist conception of the Rechtsstaat (e.g. Kelsen 1983, Hart 1994), but many legal scholars and theorists have rejected this conception. Both on historical and theoretical grounds, the latter argue that mere legality will not protect citizens from arbitrariness and authoritarian regimes. The Rechtsstaat should therefore also imply justice principles, such as human rights or respect for human dignity. According to these scholars, a legal order is not enough to constitute a Rechtsstaat. The legal order must be just in order to be a Rechtsstaat (e.g. Nussbaum 2007).

For the empirical purposes of public administration science, these debates can be pragmatically bypassed. Instead of analyzing the legal forms, legal principles, legal rights and legal institutions that constitute a Rechtsstaat, public-administration scholars can focus on the actual real-life impact of the Rechtsstaat on the design and behavior of public administration. Bypassing the doctrinal legal debate can be done by equating the Rechtsstaat with the principle of lawfulness as defined in Article 2 of the Code of Good Administration, an appendix to the Recommendation on good administration of the Committee of Ministers of the Council of Europe to member states (Recommendation CM/Rec(2007)7). Article 2 states:

\section{Article 2 - Principle of lawfulness}

1. Public authorities shall act in accordance with the law. They shall not take arbitrary measures, even when exercising their discretion.

2. They shall comply with domestic law, international law and the general principles of the law governing their organisation, functioning and activities.

3. They shall act in accordance with rules defining their powers and procedures laid down in their governing rules.

1 The German concept of the Rechtsstaat and the Anglo-Saxon rule of law are not synonymous. They are derived from different legal and political traditions and to a certain extent refer to different phenomena. In the context of this article, though, they can be used interchangeably. With regard to the relationship between the law and public administration, their core meaning corresponds. Both concepts express the principle of lawfulness, and they require public administration to adhere to the law. 
4. They shall exercise their powers only if the established facts and the applicable law entitle them to do so and solely for the purpose for which they have been conferred.

The principle of lawfulness perfectly expresses the multifaceted ideal of the Rechtsstaat. It prohibits arbitrariness, it refers to general principles of the law like legal equality and legal certainty, and it requires that the behavior and the design of public administration be in accordance with the law. The definition also includes justice principles by referring to international law in which these principles are laid down. ${ }^{2}$ The principle of lawfulness does not only express the core meaning of the Rechtsstaat. It also theoretically indicates the actual role of the law in public administration. Theoretically the role of the law in public administration is to juridify and to legalize the design and behavior of public administration. Legalization refers to the legal form which public administration, its policies, decisions and actions should take. The legalization of the powers and instruments of public administration means that these are laid down as legal powers. Juridification is a process in which political and administrative issues increasingly become legal issues to be dealt with by the judiciary. For example, if legislation increasingly encompasses a nation's education system (access to education, quality control, decision-making, course programs, the design of educational organizations, etc.), all these issues will become legal issues eventually to be dealt with by a court. If international relations are juridified, this means that they are eventually dealt with by national or international courts.

Theoretically the principle of lawfulness compels public administration to juridify and to legalize its behavior and its design. Although the principle of lawfulness thus theoretically defines the meaning of the Rechtsstaat from a public-administration perspective, we do not know to what extent the principle of lawfulness actually directs the behavior and design of public administration. Assessing the role of the law requires empirical research into administrative practices, decision-making processes within public administration and so on. Within the context of this article, it is impossible to synthesize the extensive empirical research on the role of the law in public-administration practice. The literature ranges from empirical research on the way the police deal with the law to the execution of the law in public bureaucracies and the legality of political decision-making (e.g. Pakes 2004; Posner 2008; Hawkins 2002; Bardach and Kagan 2010; Finer 1999; Wilson 1991). Instead of summarizing the extensive literature, it may be more fruitful to propose some hypotheses as foundations for a theory.

2 For example, the European Convention for the Protection of Human Rights and Fundamental Freedoms and the International Covenants on Civil and Political Rights and on Economic, Social and Cultural Rights. 


\section{Hypothesis 1 . The role of the law varies with different public- administration contexts, both within a given legal and administrative tradition and between different legal and administrative traditions.}

The first hypothesis claims that an empirical assessment of the role of the Rechtsstaat in public administration requires a balanced approach because of the variety of public-administration contexts. First, the principle of lawfulness unevenly affects different policy sectors. Some policy sectors are almost completely legalized and juridified, such as criminal policy and criminal justice administration (e.g. Pakes 2004). Other policy sectors are less juridified and legalized, such as the provision of welfare services (Zouridis 2009). In general, we may expect that the more coercive a policy sector, the more this sector will be legalized and juridified. For example, criminal justice administration is more coercive than the care for the elderly. We may therefore expect it to be more legalized and juridified. Especially the use of coercion forces governments to legalize and juridify their instruments, their organizational and process design and their actions. Coercion compels public administration to create legal controls and legal procedures because it encroaches upon fundamental rights and freedoms.

Second, the impact of the principle of lawfulness also varies with different stages of the policy process. Whereas policy development usually takes place within broad constitutional boundaries that bind the legislative power, the executive power which implements policies is more likely to be regulated in detail. The extent to which the legislative is bound by the constitution depends on the framing of the constitution. For example, the principle of sovereignty of Parliament in the English constitutional order suggests law-free politics. In practice, European law does regulate parliamentary decision-making in England (e.g. Allison 2007). In the Netherlands, the Senate of the Dutch Parliament has explicitly decided to focus on the legal quality and the legality of legislation. ${ }^{3}$ Even though the Senate is a political body with Senators directly elected by the Provincial Councils it primarily focuses on checking the legality of policy and legislation.

In theory, we may expect the judiciary to be strictly bounded by the principle of lawfulness and the rule of law, but again research shows that the reality is more complicated. Based on extensive research, Posner (2008) concludes that decisionmaking by American appellate courts is highly pragmatic. Instead of asking themselves how to realize legal goals and ideals, the courts consider the law to be marking the boundary of their discretion in deciding cases. In the Netherlands, judges and courts even disobey legislation, justifying their disobedience with legal and justice principles (De Groot-Van Leeuwen, Van den Bossche and Buruma 2006). Even though theoretically we may expect the principle of lawfulness to be omnipresent in the work of the judiciary, the judiciary regularly ventures outside the legal cage.

3 See the first annual report of the Senate at http://www.eerstekamer.nl/id/vhyxhwi8eezk/ document_extern/jaarbericht_2003_2004/f=/jaarbericht\%202003-2004.pdf. 
Theoretically the executive power of the state should be positioned between the legislative power and the judiciary. Its routines and its behavior thus should be structured or even determined by the principle of lawfulness. However, empirical research has demonstrated many discrepancies between the law and its implementation by the executive power (e.g. Pressman and Wildavsky 1973; Kagan 1978; Hawkins 2002; Bakker and Van Waarden 1999; Wilson 1991). These discrepancies are explained by the internal contradictions in the law, the discretionary power required in interpreting the law, the freedom to apply a power attributed by the law, the caseload within public organizations, the scarcity of resources in regulatory agencies, the complexity of the law and so on. The idea of the law which is straightforwardly implemented appears too simplistic. Officials and organizations that implement laws always possess a certain amount of discretionary power. It depends on the professional culture, the legal and organizational checks and the implementation style of the implementing agency whether the discretionary power causes discrepancies between actual practices and the law.

Third, the variety of public-administration contexts increases if we include a comparative perspective. For example, whether public administration is subjected at all to the principle of lawfulness depends on the legal tradition. In some legal traditions, the principle of lawfulness primarily implies that public administration is subject to religious laws. Examples of religious lawfulness can be found in the Islamic, Hindu and Confucian traditions (e.g. Glenn 2010). In the Western part of the world, the common-law tradition and the civil-law tradition differ substantially with regard to the principle of lawfulness. For example, in many ways, the United Kingdom with its common-law tradition can be contrasted with Germany with its civil-law institutions and its concept of the Rechtsstaat. In Germany, lawfulness implies compliance with the constitution and legislation, while in England, lawfulness implies compliance with the common law (e.g. Glendon, Gordon and Osakwe 1994; Seerden 2007). The impact of these legal traditions should not be underestimated. Germany's public administration is imbued with legalism and written legislation, whereas the common-law system of the United Kingdom is built upon precedent.

The administrative tradition of public administration also affects the actual role of the law (e.g. Pollitt and Bouckaert 2004; Painter and Peters 2010). Van Waarden (1999) characterizes administrative traditions on the basis of their regulatory styles, their modes of state intervention, the way these styles deal with nongovernmental organizations and their approach to implementation and enforcement. The conceptual frameworks of both Pollitt and Bouckaert and Van Waarden are predominantly built on research in highly developed countries. Painter and Peters (2010) have also taken into account other parts of the world. Their analysis shows that even the possibility of personal rule should not be excluded. For example, Jackson and Rosberg (1982) have extensively described the types of personal rule that emerged in black Africa in the postcolonial era. It appears that the basic characteristics of systems of personal rule contrast with the rule of law. In systems of personal rule, political 
machinations like plots and coups are commonplace. It seems impossible for a state to develop some sound legal institutions in the context of princely or prophetic rule.

Legal and administrative traditions thus affect the actual role of the law in public administration. Apart from strict personal rule three ideal types of legaladministrative regimes emerge from the literature:

1. Legislative legalism: in this regime, legislation and general rules are the alpha and omega of public administration. Power is concentrated, and political and administrative life is centered on the production and execution of legislation. The legislator is the key actor in the power structure. Implementation, enforcement, and adjudication are primarily matters of applying legislation. All public institutions are imbued with a spirit of legalism. Government and parliament predominantly use legislation as an instrument. Because of the importance of legislation, courts play a limited role as "bouche de la loi". Although the ideal type of legislative legalism will not occur in real life, French government comes close (see Painter and Peters 2010).

2. Court-centered constitutionalism: in this regime political, administrative and judicial life orbits around the constitution. The constitution ensures that power is dispersed. Legislation does play a major role as a source of the law, but it will be tested against the constitution by the courts. Although the administrative culture is to a certain extent imbued with legalism, above all the administration is continuously aware of the fact that any decision, policy or action has to be upheld before the court. This ideal type does not occur in real life either, but countries like the United States of America and Germany do show some resemblance to court-centered constitutionalism (Koopmans 2003).

3. Pragmatic consensualism: this regime is characterized by dispersed power, both within the organization of the state and between the state and society's institutions. Because of the need for practical solutions, legislation primarily provides the channels and infrastructure for decision-making. The law thus marks the boundaries within which politics, the administration, courts and nongovernmental organizations have to operate. Whereas the administration works pragmatically with the law, government is more concerned with reaching consensus than with strictly executing the law. The limited role of the law implies a limited role for the courts. Just like the other regimes, pragmatic consensualism as an ideal type will not occur in real life. The system of personal rule as described by Jackson and Rosberg (1982) for some sub-Saharan African countries does resemble this ideal type, but these countries are more politicized. Belgium and in certain respects Italy also show several features of pragmatic consensualism (Pollit and Bouckaert 2004). 


\section{Hypothesis 2. Despite the variety of public administration contexts, the overall picture displays a remarkable growth of the law and legislation as well as their impact on public administration.}

The first hypothesis claims that the variety of public-administration contexts requires a balanced answer to the question on the actual role of the law and the actual impact of the principle of lawfulness. The second hypothesis sharply contrasts with the first one. It claims that there is a general overall pattern despite the variety of public-administration contexts. The overall picture displays a growing role of the law. Public administration has gradually been juridified and legalized. Bardach and Kagan (2010) conclude that in recent decades, the problem of underregulation has been replaced by the problem of overregulation. The juridification and legalization of public administration have primarily been caused by a legislation boom. For example, in the Netherlands, the body of national legislation has almost doubled since 1980 (De Jong and Herweijer 2004). The growth of legislation may be attributed to objective causes like population growth, new technologies or the complexity of society. In Europe, the growth of European Union law also plays an important role (e.g. De Jong and Herweijer 2004). These causes only partly explain the omnipresent role of the law in modern public administration. The legal culture should also be taken into account. For example, while Japanese society is not much less complex than the United States, it has less than one tenth of the number of lawyers per citizen (Friedman 1994, 9). Apparently European countries have been overcome by a strong belief in the rule of law. This belief has multiplied the growth of the law and legislation and has further accelerated the juridification and legalization of public administration. However, other multipliers have also played a role.

First, laying down human rights as legal claims in constitutions and international treaties is a major cause of legalization and juridification. Citizens use these claims to fight the decisions, actions, and even policies and legislative frameworks of governments. In turn, courts have further refined the legal standards and legal principles. Second, the expansion of judicial review has multiplied both the procedural and substantial requirements for public-administration actions and decisions. The law increasingly spells out the principles and rules that have to be taken into account in order to prevent arbitrariness. Administrative courts have further refined these requirements. Third, the expansion of judicial review of the public administration's actions and decisions has forced both legislation and the public administration to explicitly pose legal standards with regard to the administration. Both codified and unwritten legal principles binding the administration nowadays exist in many European countries (Seerden 2007). 


\section{Hypothesis 3. Public-administration practice and the law have converged and are still converging.}

The third hypothesis claims that the legislation boom, the creation of legal rights and the reinforcement of legal institutions have triggered the convergence of the law and public administration. In short, there is more law than ever and there are more institutions to keep public administration within the legal boundaries. It is becoming increasingly harder to conceptualize public administration without taking the law into account. The convergence of the law and public administration has profoundly transformed both. First, as argued above, public administration's behavior and design have rapidly been legalized and juridified. Policies are laid down in legislation, decisions have become legal decisions, and relationships between administrative organs have become legal relationships. Second, because of the convergence of the law and public administration, the relationship between these two phenomena has been inverted. Whereas according to Finer, the law in ancient Sumer and Egypt could only be found "in the mouth of the king", modern European public administration is almost completely subjected to the law and legal institutions (e.g. Finer 1999). The gradual convergence of the law and public administration therefore does not appear to be a neutral historical process but a historical inversion of the relationship between the law and public administration. The rule of law has gradually displaced rule by law. Third, the convergence of the law and public administration has filled political and administrative discretion with legal rules, principles and definitions. Instead of discretionary power free from the law, contemporary law dictates in great detail how public administration should be designed and what behavior is legally acceptable. Discretion nowadays only arises by accident if the law outlines contradictory rules, principles, or definitions.

\section{Functions and dysfunctions of the Rechtsstaat}

Lawyers and legal scholars regard the observed convergence of the law and public administration as natural or even trivial. They welcome the convergence of the law and public administration as the ultimate realization of the ideal of the Rechtsstaat. As arbitrariness diminishes and compliance with the principle of lawfulness continues to grow, the ideal of the Rechtsstaat will be achieved in time. Instead of the whims of a ruler, citizens can now increasingly rely on the law and legal institutions. Legal equality and legal certainty are finally embedded in the actual behavior of public administration. Nevertheless, public-administration scholars should more critically assess the convergence process than lawyers and legal scholars. As argued, the principle of lawfulness compels public administration to juridify and to legalize its behavior and its design. These consequences will undoubtedly produce the functions heralded by lawyers and legal scholars, but a balanced account of the Rechtsstaat should also consider the dysfunctional effects of juridification and legalization. At what cost has the convergence process taken place? 


\section{The impact of convergence on public-administration practice}

The blessings of legalization and juridification are obvious. Citizens' rights can be enforced because of legal protection and legal equality. Benefits, permits, and freedoms have been transformed from favors of the ruler into rights and legal entitlements which citizens can legally enforce. It has become increasingly difficult for public administration to make arbitrary decisions that affect citizens or even other parts of public administration. Because of the need to base its behavior on legal standards, norms and rules, public administration has become more objective (e.g. Greenawalt 1998). Because of the convergence process, however, public administration now has new problems to cope with.

First, juridification and legalization have lessened the discretionary power of politics and democratic institutions. ${ }^{4}$ Political power is increasingly caged by the law and legal institutions. For example, even the traditional sovereignty of British parliament has been encroached upon by European law (e.g. Allison 2007). Second, because of the legislation boom, the problem of arbitrariness has now taken a new shape. Rules increasingly contradict or overlap. In the Netherlands, a famous example can be found in the regulation with regard to the floors of restaurant kitchens. Whereas labor law obliges restaurants to install slip-resistant floors in their kitchens to prevent staff from slipping, the law on food hygiene requires restaurants to install polished floors. From the restaurant owner's perspective, the behavior of public administration therefore has become arbitrary. Third, the extensive legal procedures and formal requirements threaten the effectiveness and the efficiency of public administration. Apart from the dysfunctions of outdated procedures and legal requirements, the sheer number of litigation procedures sometimes obstructs political decision-making. Carlens and Verbeeck (2007) have described the effect of an extreme form of legal protection in the Flemish Municipalities Act. Because of the infinite possibilities to complain, the Flemish sea-side town of Blankenberge even accused one of its citizens of stalking the municipal authorities. After losing the exclusive right to use a pétanque field in a public park, the chairman of the aggrieved pétanque club filed hundreds of complaints against the local authorities (Carlens and Verbeeck 2007, 2). Finally, the convergence of the law and public administration has led to an unbearable law-enforcement burden. The more the law and public administration converge, the more the enforcement of the law becomes a legal obligation assigned to public administration. While society guarantees compliance with social norms and standards, public administration has to safeguard compliance with legal standards.

\section{The impact of convergence on the law}

The convergence process also affects the law. At first glance, the law only seems to gain from its convergence with public administration. Its supremacy is strength-

4 As argued by a Dutch commission led by former Queen's Commissioner Van Kemenade in 1997. 
ened, its rules and principles are increasingly backed by the powers of the state, and its values have become widespread. Still, the convergence process has also affected both the use of the law and the modality of the law. First, the convergence process has connected the law with political and administrative goals. Nonet and Selznick (1978) have extensively analyzed the effects of such a connection by distinguishing three basic modalities of the law. In its repressive form, the law served repressive political and administrative power. The law was then regarded as the order of a ruler. With the growth of the Rechtsstaat, the law and its institutions became more and more independent from the ruler. Its goal increasingly became taming repressive force and preserving the integrity of the law and its institutions. The convergence of the law and public administration has triggered the third basic modality of the law as distinguished by Nonet and Selznick (1978). The law increasingly responds to the needs and demands of society and politics. The law in its responsive mode merely channels these demands and social goals. According to Nonet and Selznick (1978, 117), the law even dies in its responsive mode. They argue:

In both its repressive and its responsive modes, the legal order loses the protection of firm institutional boundaries and becomes an integral part of government and politics. Hence, there is an attenuation of "distinctively legal" ideas and modes of thought. The death of law, in that sense, is a mark of both stages. In both repressive and responsive law the authority of rules is weakened; discretion is enlarged; an instrumental perspective undermines the formalism of "artificial reason"; legal argument is less easily distinguishable from policy analysis; and legal institutions become at once more accessible and more vulnerable.

The close connection between the law and public administration thus will also affect the way the law is used and respected. Because of the convergence, the law may only become a tool of government meant to serve instrumental purposes. Its normative and protective functions are subordinated to the political and administrative goals laid down in the law. Hence, the convergence process fosters legal instrumentalism by politicians, public managers, policy makers and front-line administrators. Political and administrative goals are laid down in legislation, and legal institutions are used to enforce these goals. As Tamanaha (2006) has argued, this will eventually threaten the rule of law. He defines the rule of law as the idea "that the non-instrumental views of law established legal limits on the law itself". According to Tamanaha $(2006,219)$ the inner morality of the law will be lost because of widespread instrumentalism. He argues:

When law was thought to have an inviolable, built-in principled integrity, invocations of that core provided a source within law to resist malign uses of the law. Instrumentalism, in contrast, entails only means-end reasoning. Once an end has been decided upon, 
law can be used in any way possible to advance the designated end, without limit. Instrumental questions may be raised about the efficiency of law in achieving the ends designated, but as long as the formal or procedural requirements are met, there can be no legal objections against using law in an abhorrent or evil fashion. Moral opposition may be raised to such repulsive uses of law, but it will back legal standing - a difference that matters mightily in the realm of symbolism and political discourse.

\section{Building blocks for a public-administration research agenda}

The effects suggested above constitute a research agenda on the Rechtsstaat from a public administration perspective. Comparative research should show whether these effects in fact occur. It also enables us to scrutinize which legal designs and which interpretations of the principle of lawfulness predominantly produce dysfunctions. The convergence of the law and public administration therefore should be a key issue on the public-administration research agenda. Studying the convergence of the law and public administration requires comparative research in which the concept of the Rechtsstaat is used in its empirical sense as a principle of lawfulness. Lawyers and legal scholars may be biased by the ideal of the Rechtsstaat, but to public-administration scholars, it is just a design for government and governance. Comparative research has to prove what design of the Rechtsstaat and the principle of lawfulness ensures a more effective, efficient, legitimate and stable public administration.

Research on the convergence of the law and public administration also requires multi-disciplinary research. What legal concepts, rules and principles lead to bureaucratic unreasonableness or inefficiency? What legal designs stimulate the effectiveness, efficiency and legitimacy of public administration and simultaneously contribute to core legal values such as legal equality and legal certainty? Many governments and public institutions are aware of the urgency of these issues, but these questions remain unanswered because of the current disconnection between legal and public-administration research. Especially in Eastern Europe, governments are still developing their legal frameworks. They do not suffer from the path dependency that caused legalization and juridification in Western Europe and the United States of America. So why not pick up the challenge and renew an old European public-administration-discipline tradition that was abandoned for good reasons but now seems more challenging than ever? 


\section{References}

Allison, J. W. F. 2007. The English Historical Constitution. Continuity, Change and European Effects. Cambridge: Cambridge University Press.

Bakker, W. and F. Van Waarden. 1999. Ruimte rond regels: Stijlen van regulering en beleidsuitvoering bekeken. Amsterdam: Boom.

Bardach, E. and R. A. Kagan. 2010. Going by the Book: The Problem of Regulatory Unreasonableness. New Brunswick, New Jersey: Transaction Publishers.

Carlens, I. and B. Verbeeck. 2007. "Protecting the Citizen, Protecting the Local Administration: The Flemish Case." Paper presented at the annual meeting of EGPA Study Group on Public Administration.

Cooper, P. J. 2007. Public Law \& Public Administration. Boston, MA: Wadsworth.

De Groot-Van Leeuwen, L. E., A. M. van den Bossche and Y. Buruma (eds). 2006. De ongehoorzame rechter: Rechters versus andere rechters, de wetgever, de bevolking en het Europees recht. Deventer: Kluwer.

De Jong, P. O. and M. Herweijer. 2004. Alle regels tellen: De ontwikkeling van het aantal wetten, AmvB's en ministeriële regelingen in Nederland. Den Haag: Boom.

Finer, S. E. 1999. The History of Government from the Earliest Times. 3 vols. Oxford: Oxford University Press.

Freeman, M. D. A. 2001. Lloyd's Introduction to Jurisprudence. London: Sweet \& Maxwell.

Friedman, L. 1994. Total Justice. New York: Russell Sage Foundation.

Glendon, M. A., M. W. Gordon and C. Osakwe. 1994. Comparative Legal Traditions: Text, Materials and Cases. St. Paul: West Publishing.

Glenn, H. P. 2010. Legal Traditions of the World. Oxford: Oxford University Press.

Greenawalt, K. 1998. Law and Objectivity. Oxford: Oxford University Press.

Hart, H. L. A. 1994. The Concept of Law. Oxford: Clarendon Press.

Hawkins, K. 2002. Law as Last Resort: Prosecution Decision-Making in a Regulatory Agency. Oxford: Oxford University Press.

Jackson, R. H. and C. G. Rosberg. 1982. Personal Rule in Black Africa: Prince, Autocrat, Prophet, Tyrant. Berkeley, CA: University of California Press.

Kagan, R. A. 1978. Regulatory Justice: Implementing a Wage-price Freeze. New York: Russell Sage.

Kelsen, H. 1983. Reine Rechtslehre. Wien: Deuticke.

Koopmans, T. 2003. Courts and Political Institutions: A Comparative View. Cambridge: Cambridge University Press. 
Lynn, L. E. 2009. "Restoring the Rule of Law to Public Administration: What Frank Goodnow Got Right and Leonard White Didn't." Public Administration Review 69, 803-812.

Nonet, Ph. and Ph. Selznick. 1978. Law and Society in Transition: Toward Responsive Law. New York: Harper \& Row.

Nussbaum, M. 2007. Frontiers of Justice: Disability, Nationality, Species Membership. Harvard: Harvard University Press.

Painter, M. and B. G. Peters (eds). 2010. Tradition and Public Administration. New York: Palgrave Macmillan.

Pakes, F. 2004. Comparative Criminal Justice. Portland, OR: Willan Publishing.

Pollitt, C. and G. Bouckaert. 2004. Public Management Reform: A Comparative Analysis. Oxford: Oxford University Press.

Posner, R. A. 2008. How Judges Think. Cambridge, MA: Harvard University Press.

Pressman, J. L. and A. Wildavsky. 1973. Implementation. Berkeley, CA: University of California Press.

Seerden, R. J. G. H. (ed.). 2007. Administrative Law of the European Union, its Member States and the United States: A Comparative Analysis. Antwerp: Intersentia.

Tamanaha, B. Z. 2006. Law as a Means to an End: Threat to the Rule of Law. Cambridge: Cambridge University Press.

Waarden, F. van. 1999. “Ieder land zijn eigen trant?" In Bakker \& Van Waarden 1999, 303-339.

Wilson, J. Q. 1991. Bureaucracy. What Government Agencies Do and Why They Do It. New York: Basic Books.

Zouridis, S. 2009. De dynamiek van bestuur en recht: Over de rechtsstaat als bestuurswetenschappelijk fenomeen. Den Haag: Lemma. 